\title{
THE IMPLEMENTATION OF URBAN SPACE SUSTAINABILITY FACTORS IN DESIGNING THE NEW CITY OF ALI SHAHR
}

\author{
Mahnaz Alimohammadi \\ Urban Design graduate from the Faculty of Arts and Architecture, Islamic Azad University, Tehran center \\ Davood Safdari \\ Urban Design graduate from the Faculty of Arts and Architecture, Islamic Azad University, Science and \\ Research Branch, Tehran \\ Davood.Safdari@,Yahoo.com
}

\begin{abstract}
A consideration to the experiences of new towns in Iran, as a new movement in contemporary urbanism attitude, shows this fact that there is no considerable attention to the matter of public urban space in the field of urban design. On the other hands, we can obviously perceive the roles of public urban space in historical urban tissues in distinctive scales which could be durable throughout the centuries. With Detailed regarding to the products of urban design in new towns, we can reach the important issue that-instead of great attention to the climatic parameters in design of urban space of ancient tissues-- these ancient effective climatic factors have less influence on process of designing public space. This Paper tries to revise the current situation and design the open spaces in Ali Shahr, with precise regarding in climatic patterns of ancient city of Bushehr. The importance of this issue can be more intensified when know these ancient tissues satisfy the amenity of spaces and support the pleasure and variety of different activities, with considering in climatic parameters in designing of urban spaces. From a reasonable standpoint, this Paper-- with emphasizing at process of urban space's generation in district no2, phase no4 and the role of climatic factors in shaping these spaces and also the influence of these spaces to increase identity of the city -- tries to achieve appropriate design principles, according to climatic design parameters of historical tissue of Bushehr.
\end{abstract}

Keywords: climatic patterns, sunshine, wind flow, Bushehr, the new town of Ali Shahr

\section{INTRODUCTION}

Under the provisions of Article 1 of the establishment of new cities in January 2001 approved by the Assembly, and Article 2 of the Executive Regulations in August 2003, which has been approved by the Cabinet, new town refers to the population points located outside the privacy of towns to resettle at least thirty thousand people along with buildings and public, social and economic facilities for residents within the framework of Iran's Supreme Council for Planning and Architecture. The need to build a new town with a population in accordance with government policies in the national, regional or local physical design by proposal of Department of Housing and Urban Development was approved by the Supreme Council for Planning and Architecture in Iran. After notification of the Supreme Council, the builder prepares a comprehensive plan of building a new city. Under the mentioned laws and regulation, New Towns Development Corporation as a holding company, established in 1989 according to the policy by the Ministry of Housing and Urban Development for planning, coordination and supervision of the design and implementation of new towns. Since 1989, the company fulfill their mission to establish 22 new towns construction companies as a subset of the parent company. (Aghighi, 2009: 27)

After two decades, it is a relatively good time to evaluate and judge any policy or program, particularly, when the country is in new selection and a new experience in the field of policies and programs, especially if those policies are experienced in the period, when wide and varied range of those programs 
had been experienced (Zanjani et al., 2009: 6). Experience of new towns in Iran is indicative of this claim that new towns are recognized to settle the overflow population in a rapid process and street are considered as separators and by ignoring the urban spatial concepts in the design of public areas, social presence is in a new city will be lost (Abedi et al., 2009: 76). The public realm that is the most neglected part of the new cities, is a place where interactive dialogue among citizens take place face to face, but now lack of attention to the qualitative aspects of urban design in the cities and focusing solely on physical-biological aspects of human induced the formation of two-dimensional design, chess streets and blocks on the sidelines. As stated the objectives of building a new town has been proposed as reserves of population additions of metropolitan cities during the past two decades. And with this kind of attitude, a kind of design is presented regardless of the value, with the same height. Lack of attention to the further development of the city and the importance of keeping the population, lack of attention to collective memory, creation of public spaces and lack of attention to social needs and recreation centers for the residents are some examples which has not been considered in these cities. However, the establishment of new city can bring people life, where a new starting point in the life of its inhabitants can be created. (Bagheri Shahid, 2006: 61)

A series of studies and research in the field of sustainable urban design, followed by discussion about sustainability, mainly three components of environment, social and economic exist of which the environmental component physically emerges other than two components in the city. Therefore, we can say that due to environmental factors of design platform, has an important role in the urban public space. Regarding this subjective background, it can be understood, that in particular climatic areas, considering affecting climatic variables and components plays a pivotal role in public space design process. Clever attention to historical urban tissues that preserved their value over a period to date obviously lie ahead a unique position of urban public spaces in different scales. The vibrancy of these spaces can help much to the richness of the city in various fields of social, physical and economic aspects.

Implementation of this attitude in traditional urban design of Iran indicate that although climatic design components are considered in major old towns in multiple climatic areas, a good look at the process and product of urban design in new towns indicates an opposite situation. This paper aims to review the concepts of urban public spaces, followed by a lively urban public space based on efficient and effective climatic components in the formation of such spaces to provide more access to the identity of towns as a new tradition of urbanism in Iran; on the other hand it aims to provide the necessary conditions for greater participation of the lively urban public spaces based on climatic patterns in the design of new towns. In this context, the new city of Ali Shahr in Bushehr province which has a hot and humid climate is studied due to the patterns of climatic design patterns in the public spaces of the old tissues and lack of physical patterns in urban spaces of Ali Shahr and is used to develop final criteria.

A view on the results of activities in the field of urban design in the city shows that the urban public spaces as an integral part of urban design has received little attention. Given the key role of these spaces in creation of an atmosphere of interaction and creation of a collective memory and the promotion of urban identity, obviously we have to redefine the role of urban public spaces in the design of the new town of Ali Shahr. This paper seeks to address the role of climatic patterns on the formation of urban spaces of Bushehr historical tissues, to discuss the role of this important issue in urban spaces of Ali Shahr in terms of design process. Ali Shahr need for a redefinition as a new town in the review of the current situation. The significance of this issue with regard to the particular climatic conditions in Bushehr region is increased, because in such areas, environmental criteria in urban design, provides welfare of citizens and dynamic activities in urban space. Despite the compact city pattern in formation of Bushehr tissues and with environmental standards, physical and urban design in Ali Shahr shows a different situation. In this paper, with emphasis on the manufacturing process of urban public spaces in Ali Shahr and the role of climatic factors in the formation of these spaces and the effects of these spaces in the development and upgrading the urban identity, a necessary precondition for achieving an 
appropriate pattern in designing urban public spaces in accordance with climatic design criteria will be provided.

\section{RESEARCH OBJECTIVES}

(1) Achieve an appropriate pattern for urban public spaces based on its relationship with climate

2. The typology of urban public spaces in the old tissues of the Bushehr to introduce design patterns of these spaces in new towns

3. Determine the criteria guidelines for urban design in urban public spaces of Ali Shahr based on the climatic elements of architecture and urbanism

\section{METHODS}

The basic method in this research is comparative-analytic method. It should be noted that due to multipart nature of the study, different methods are used in each part to achieve the goals. The library method was used to evaluate different approaches and $\backslash$ historical research was used to examine the changes and tissue analysis for a historical period; observation and field study was used to collect information.

\section{BUSHEHR AND ARCHITECTURE AND URBAN CLIMATIC PATTERNS OF ANCIENT TISSUES}

The main issue in today's world of contemporary architecture and urban planning, is the separation of link between domestic architecture and urban planning, and modern requirements. It is necessary to remind methods used in the ancient world as a symbol of green solutions and adapt them to the new world by the technological advances of our time. The necessity for reviewing past solutions to adapt to difficult climatic conditions is that architecture and urbanism of those days were a local sustainable process that has been transferred from a generation to generation over a long time by trial and error for hundreds of years. Then sudden interruption of this process by faster and easier solutions of modern architect and urbanism forced us to forget all environmental methods. In this part of the article, we tried to study the traditional local architecture and urban planning strategies of Bushehr in accordance with adaptation to climatic conditions of the region, especially at the times when human had to use natural $f$ clean energy to learn valuable lessons in architecture and urban planning of new towns as a new movement in urbanism and architecture.
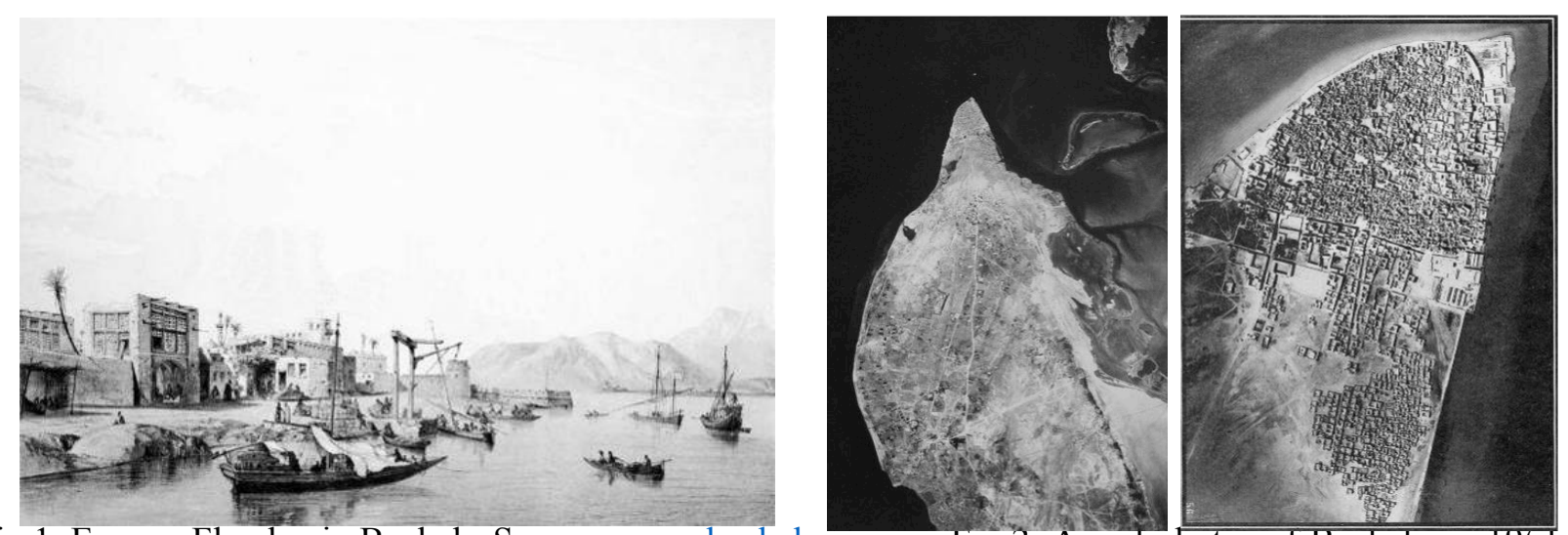

Fig 1. Eugene Flanden in Bushehr Source: www.bushehrema.1r Fig 2. Aerral photos of Bushehr in 1951 and 1956 Source: geographical organization of Iran archive

In traditional Iranian architecture and urban planning, adherence to the influence of climatic factors can be seen clearly in the tissues of urban physical structure and the design of architectural monuments. The study of this issue is provided more in areas with a specific climate. This traditional Iranian architecture and urban planning, can be seen in Yazd, Kerman, Tabriz, Isfahan and major historical tissues of Iranian 
towns. Climatic factors in formation of tissue of towns that still part of their historical tissues are visible can be examined and considered. With this introduction and based on presented materials, in this section of the article, hot and humid climatic of the Bushehr region in Iran is emphasized and climatic factors in architecture and urbanism in historic tissues of Bushehr as a reference guidance of urban design will be discussed. The necessity to view Bushehr ancient tissues as a reference to the climatic design is due to the fact that the design substrate, i.e. new city of Ali Shahr, is a subset of its upper area of the city of Bushehr. Due to climatic conditions and characteristics and geographical location of Bushehr, it can be concluded that the conditions create some major limitations for the human environment; these restrictions that often emanating from the effects of the sun and the wind and the overheating of the buildings at hot periods, disrupt the comfort in a domestic spaces. Now the use of mechanical devices such as air conditioners and systems are enough for tolerable conditions inside the municipal buildings. However, adopting climatic designs related to consistent and experienced architecture and urban design are considered as the basic conditions for optimum productivity of factors and climatic factors in this case. The climatic designs in this area often include goals such as utilization of daily fluctuations in temperature, protect buildings against radiation, permanent and effective ventilation. It is clear that achieving any of these objectives above is possible by using various methods (Givoni, 1994: 56). This situation in Bushehr provides a suitable climatic conditions for the recognition of design strategies in summer climatic conditions. Basically, it can be stated that in the ancient zones, everything was under the influence of climatic conditions and were largely influenced by comfort and the physical appearance of tissues are in accordance with the theme. This is obvious in the tissues of the Bushehr with hot and humid climate such as Bandar-e Lengeh, Bandar-e Kong, and Siraf. Like hot and humid climatic zones, adequate ventilation and shading is the most important climatic issues in the tissues of Bushehr. In the ancient tissues of Bushehr, prediction of climatic design solutions in a hierarchy can be seen from urban to architectural space and spatial structure of tissue is influenced by climatic conditions, though the role of social and security factors in this area cannot be ignored. So we can say that two elements of the shading (sunlight) and wind are crucial elements in the formation of tissues in Bushehr. (Ranjbar, 2007: 5)

\section{climatic location of the historical tissues}

In locating historical tissues of Bushehr in comparison with other cities in hot and humid climate, one should refer specific position of tissues as peninsula. The privileged position provides the possibility of wind blowing in several directions and the wind speed is higher here. It has been one of the factors that caused the tissues of Bushehr with rarely signs of wind. Unlike Bushehr old tissue formations in cities such as Bandar-e Lengeh, Qeshm, Bandar Abbas and Siraf are in linear form on the edge of the beach, and that is why big wind towers in these areas are facing the sea to make the most of the sea breeze. This particular form of Bushehr tissue formation and streets orientation towards the sea provided the penetration of wind flow into the tissue. Although the orientation of the building blocks was fundamental factors to absorb the least amount of sunshine and most buildings are in east-west elongation. The location and multiple direction of wind has caused the formation of the blocks in different directions. Aside from this, the position of tissues in relation to land and topography, is in relation to climatic condition. (Rajaee et al., 2006: 64) Earth's natural state where historic tissues are located on is in a form that the eastern part is higher than the western part. This means that in the eastern part, the building height is shorter. If height complies with topography, a tissue formation orienting to the west was used to receive more heat. On the other hand created step could decrease the amount of shading on buildings. Another issue that has to be considered in this regard can be lower level of underground waters due to the higher height in the eastern part of the earth. This solved the need to create downstairs in the eastern part to avoid moisture.

\section{protection against sunlight and hot air}

However, the direct influence of the sun to the interior spaces in the cold season can help to the natural heating of spaces. But during the warm months, these causes these spaces to be too hot and humid and from this point of view, it is considered as negative factor. Thus, according to conducted analysis in 
literature and historic tissues of Bushehr, using the following methods could reduce the warmness of interior and exterior spaces to a minimum:

- In urban design, integration of traditional buildings, narrow and irregular streets and compact texture of city with high walls provided maximum shade and sunlight. These spaces and elements, provide cooling and ventilation in urban areas to provide comfort. (Consulting Engineers of City and Planning, 2003: 168)

- Partially covers of pedestrian paths through the masses provides maximum shadow on the surface of the land, which can be seen in various parts of the urban tissues in the region.

- Traditional architects consider details in their designs such as troughs and ridges, which provide the maximum shadow. Other details included in the design of this buildings are "shelters" of roofs. Since the roof top receives maximum amount of sunlight in comparison with other parts. Sometimes in these areas, "shelter" with height of 2 meters are recommended to reduce thermal radiation to a minimum with providing the maximum shade for the roof. Although long shelters offer additional benefits such as establishing protected private space in the roofs and protecting rooftops from dusty desert winds.

- Double ceilings is another method of adaptation to hot and humid climate. Very low air capacity between the two shells works as insulation. And, therefore, less heat is transferred into the interior space, and the inner shell will be cooler than the outer layer.

- The establishment of the building to minimize solar radiation. (Givoni, 2003: 88)

- Select a suitable building materials in order to minimize heat.

- Use deciduous trees to create shadows on the building.

- Establishing main spaces on courtyard or outdoor in the shade.

- Use common set of building walls and creating a compact texture.

- Use bright colors and smooth surfaces in the roof and exterior walls facing the sun in the summer

- saliency on roof, covered porch or balcony to create full shade on the outer surface of the window and openings the walls facing the sun and use proper shadings.

- The use of outer space, suitable for use when the weather is bad.

- Cover the exterior walls with appropriate materials and compact structure prediction. (Givoni, 1998: 225) 


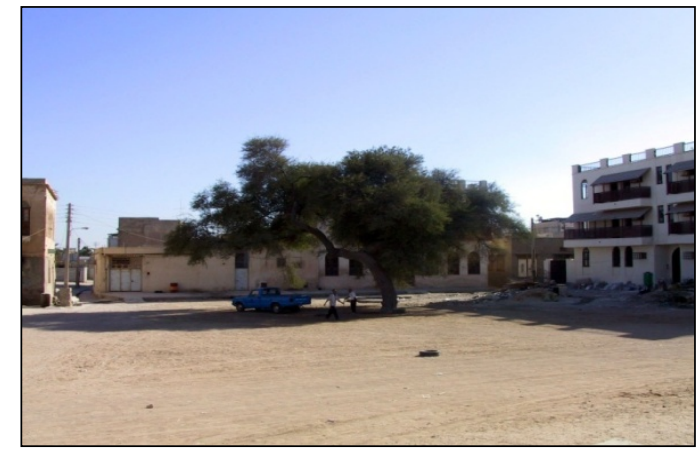

Fig 4 : Use deciduous trees Source: authors (2008)
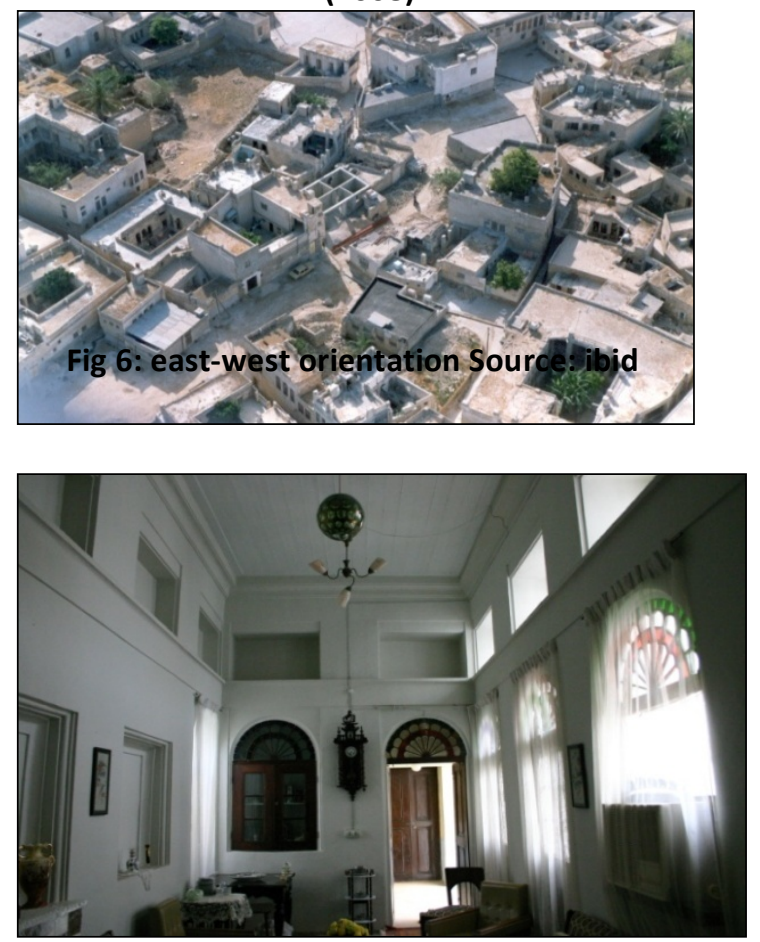

Fig 8: high ceilings Source: ibid

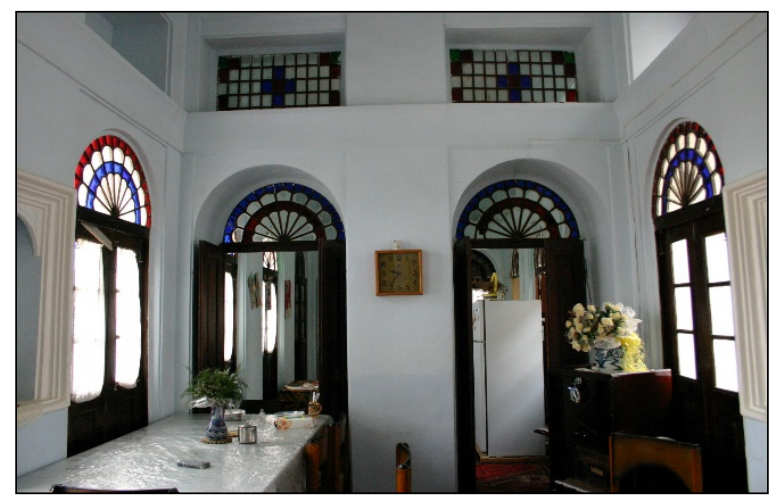

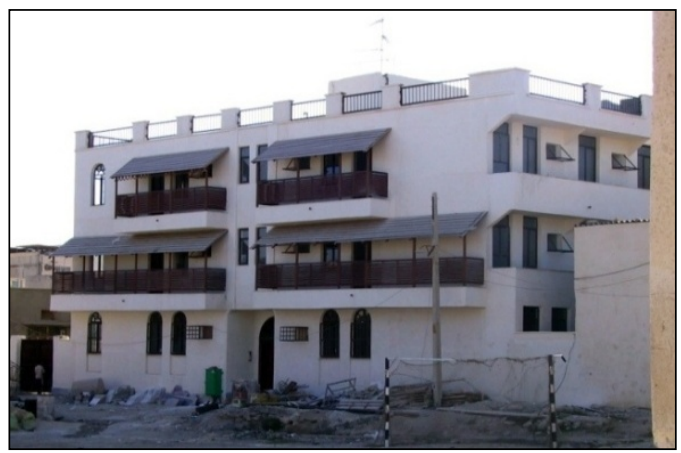

Fig. 3: Use bright colors and smooth surfaces in the roof and exterior walls facing the sun Source: Jabarnia
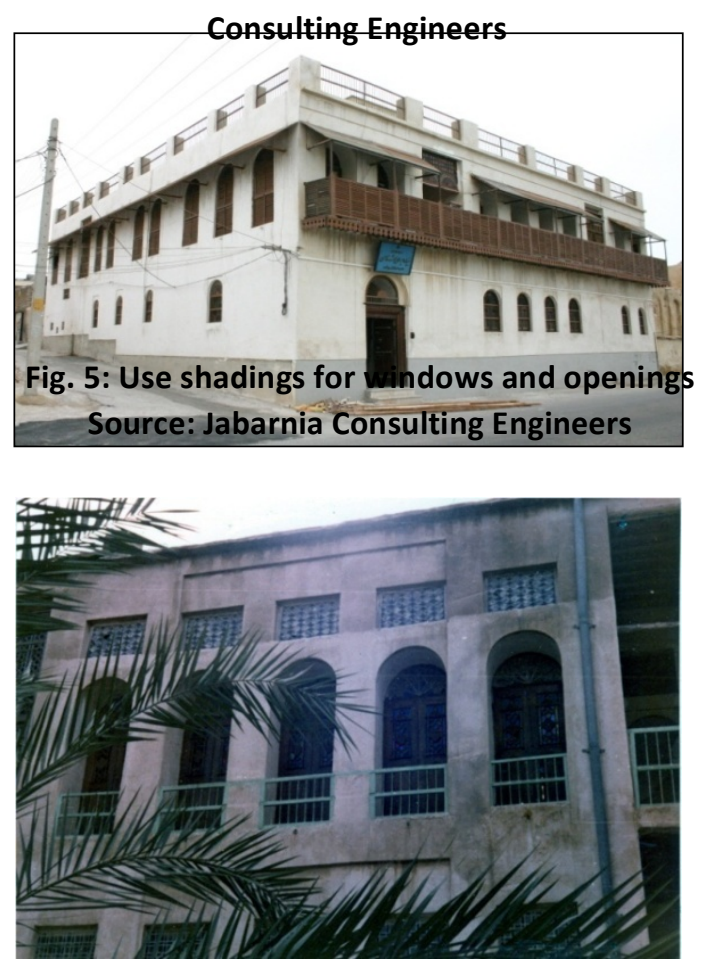

Fig 7: Rear openings Source: Bushehr
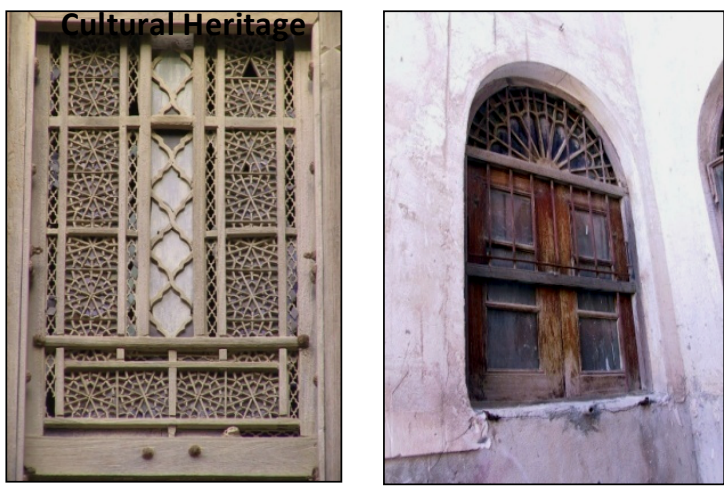


\section{Utilization of Winds}

Establishment of effective and continuous ventilation to maximize air flow in monuments and historic tissues of the city has been done in several ways:

- The height of buildings tend to have Draft (sea breeze) in summer

- The immediate vicinity of the closed space with open space

- curved protrusion and torsion of the outer body of the building, known as the whipping wind; as the wind will be directed towards the bottom of the building.

- Micro and small urban blocks, perhaps it could be stated that there is no much division and city blocks in any city in the history of Iran in the same area. This tendency is nothing more than a climatic factor and it is due to the need proper air flow in the inner space. The consequences of such strategy are:

- Create an intertwined network of urban streets

- The creation of numerous intersections

- Change the nature of passages to primary and secondary grades

- High use of land by urban streets which is a significant fault

- Narrow width passages that in fact compensates the defect in the fourth consequence. It has three advantages: First, reduced passages in the occupation of the land, second: create more shadows in the streets, and third urban passages to enter the breezes to the heart of the city (Jabernia et al. Consulting Engineers, 1999: 245)

- Other strategies are scattered squares in the neighborhoods according to environment. And regardless of their random circumstances or tactful form they have their own values and psychological atmosphere. Wind energy potential which is created by convergence and contrast adjacent buildings with diverse views in tight alleys is released in an open space which is very pleasant. (Jenab, 1994: 58)

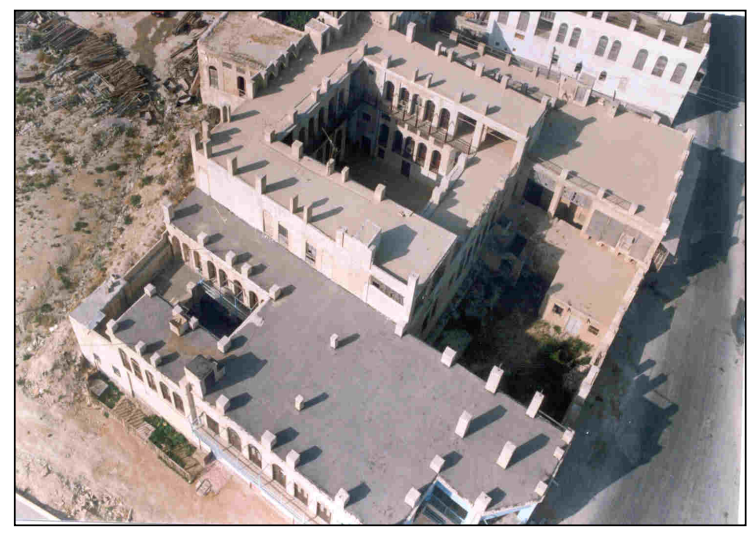

Fig. 12: increasing the height of the central spaces, Source: ibid

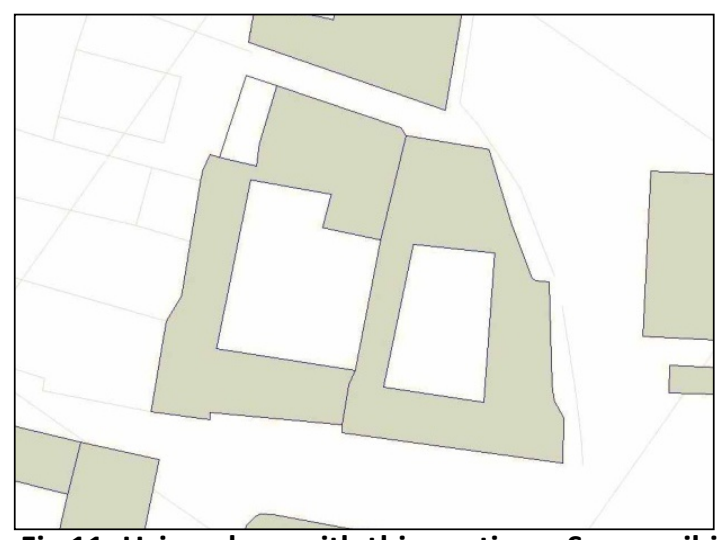

Fig 11: Using plans with thin sections, Source: ibid

\section{spatial structure influenced by climatic and social traditions}


Bushehr general tissue space is formed by a combination of building mass and open spaces between buildings. The open space includes spaces between buildings, streets and open spaces of neighborhood that in some cases are the center of the neighborhood. Courtyards of buildings in combination with these open spaces, create a balanced mix of mass and space in the tissue. Streets lead the wind into the tissue and open spaces help distribution of the air flow from the sea. The formation of the building blocks is in such a way that the form of small single house is with crossover passages around them, so that maximum flow through the masses will be created. As mentioned above, the main objective in a hot and humid climate is to provide of the air flow around the blocks. This is clearly seen in the tissues of Bushehr. With this regard, the formation of streets, open spaces and mass construction in Bushehr has formed four main areas: Kuti neighborhood, Behbahani neighborhood, Shanbadi neighborhood and Dehdashti neighborhood. Each of these areas have a center, next to the mosque in the neighborhood. Kuti neighborhood center is next to the Mosque of Sheikh Saadoun (Sadan), and centers of neighborhoods like Behbahani, Shanbadi and Dehdashti were formed next to mosques with somehow same name. Apart from the Kuti neighborhood with much of it remaining currently, the other neighborhoods are experiencing deep structural changes. It should be noted that the open areas are also form alongside the Jome mosque, Kazerouni mosque, Haj Maryam mosque. In general, in every mosque next to the historic tissues of Bushehr and an open space can be seen, which indicates combination of social customs with the climatic atmosphere. In this section, we should note that the tradition of public ceremonies related to Ashura rituals is in the context of Bushehr is rooted in the communities and much of central importance in the context of Bushehr areas as public spaces of the city are based on this tradition. Events such as chorus, shoring will be held in the old tissues of Bushehr. In addition to holding these rituals with music, learning books related to the ceremony in the past has been a duty on teens in the old neighborhoods.

\section{Public Open Spaces}

As mentioned above, public open spaces in the tissues of Bushehr in addition to social functions, perform air flow in the passages. These spaces in old tissues of Bushehr have been divided into two categories: the first category spaces are the intersection of streets. And the second are the spaces near the public elements such as mosques for social uses. Important parts of these areas are centers. Given the importance of these spaces, creation of maximum climatic comfort conditions for the people in space has been designed as one of the basics. In a comparative study based on aerial photographs taken in 1956 and 1973 at two different times of day, the amount of light in public spaces was studied. Aerial photographs in 1956 at 4 5 o'clock in the afternoon and aerial photos of 1973 at 10-11 o'clock in the morning were provided. Examining the conditions of public spaces in these two pictures suggest that most of the spaces (more than 50 percent are in the shade. (Fig. 17), the shadow formed in particular under two causes: one is the height difference of buildings around the space; that in most cases, a building higher than the rest of the buildings had been created. And the other cause is formation of public space. On one hand fit width and height of the space caused shadows and other organic forms and irregular protrusion of space and space provides more shadow. At this point, it should be noted that the presence of high buildings at the edge of space disturbs the prevailing winds and the flow toward the ground level. Another important issue in the design of these spaces, along with environmental considerations, is people presence and providing seating furniture in the space. The remaining photos of the Dehdashti and Kuti neighborhoods display this issue (Fig. 14 and 15). It should be noted that in the context of Bushehr with the openings of buildings to public spaces lead to form specific identity of these spaces in the design introverted and extroverted northern part in hot and dry regions. The opening of the openings into the public space provides common areas in several aspects. However, due to the strategic position of the historic tissues of Bushehr, these openings should not be ignored as defensive aspect. Aside from the issues raised in climatic considerations, the formation of the organic tissue as well spaces and passageways increased the sense space and historic tissues of Bushehr takes place in relation to this topic. The situation can be observed in the streets surrounding public spaces and streets that once open to the sea. 


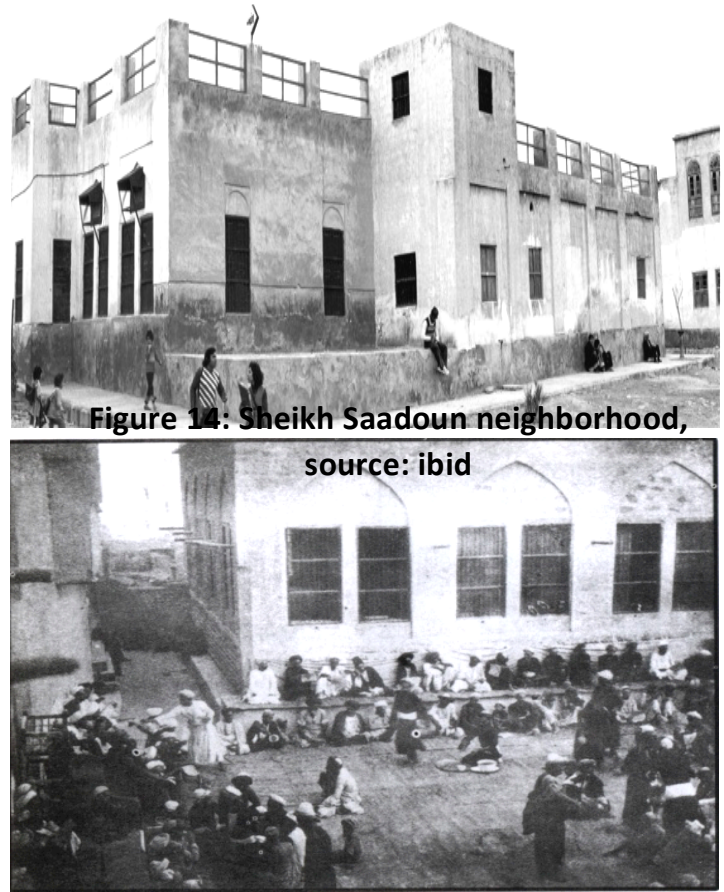

Fig. 15: Jome Mosque, source: ibid

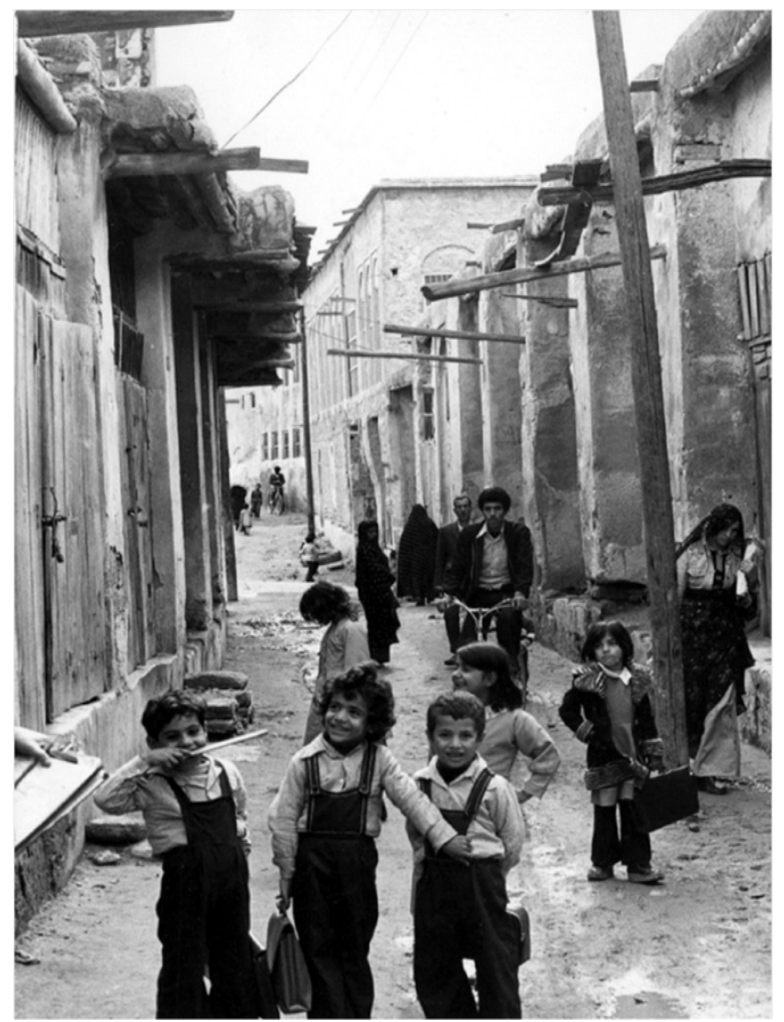

Fig 13: Behbahani's neighborhood, source: Bushehr Cultural Heritage
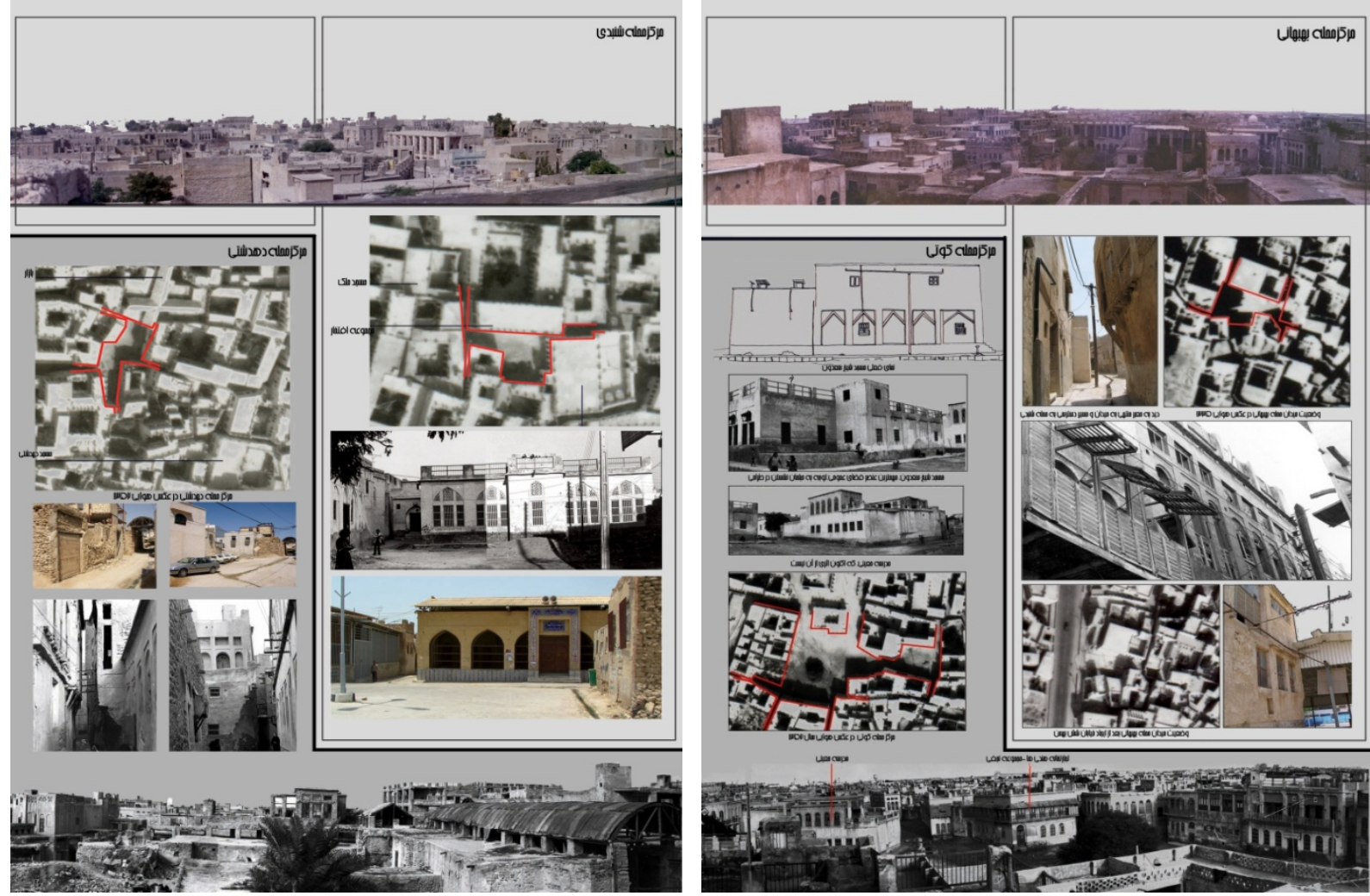


\section{role of climatic factors in the formation of passages}

The most important factor in the formation of passages network is climatic conditions, including temperature, humidity and the wind direction. Harmony in the width and height of the passages is in such a way that passages are in the shade at most times of day. Aerial photos of 1956 and 1973 clearly shows this. Proportions of width to height ratio is at least 1 to 2 as the ratio becomes 1 to 6 too (Figure 17). The numerous intersections in passages in this tissue with open spaces, provide the possibility of wind distribution in the streets. Main thoroughfares are oriented facing the sea to get the maximum wind and provide the possibility of further sea breeze into the tissue. Narrow passages in addition to providing shade allow more draft. Arrangement of buildings on the edge of the passages do not follow passage length. This leads more wind collision and its entrance to the interior space of building. The emergence of the first floor in buildings can be seen clearly as the result of this issue. In these tissues, Blind alley is rare seen and blocks are surrounded by streets to enjoy maximum air flow. Drafts in addition to lowering the humidity of the air and creating comfort temperature, absorb humidity of on both sides of the alley. Drying walls due to the use of local building materials, porous rocks, absorbs the moisture of interior space. In fact, by creating drafts in passages, moisture of interior space will be diverted through the wall.

\section{spatial order in buildings masses}

Building methods, forms and materials in the architectural tissues of Bushehr depicted a coordinated and integrated view as the spatial structure of the tissue in response to residents living culture, environmental and climatic condition of the region is unique; which is in consistent with climatic extroversion and biological introversion. 


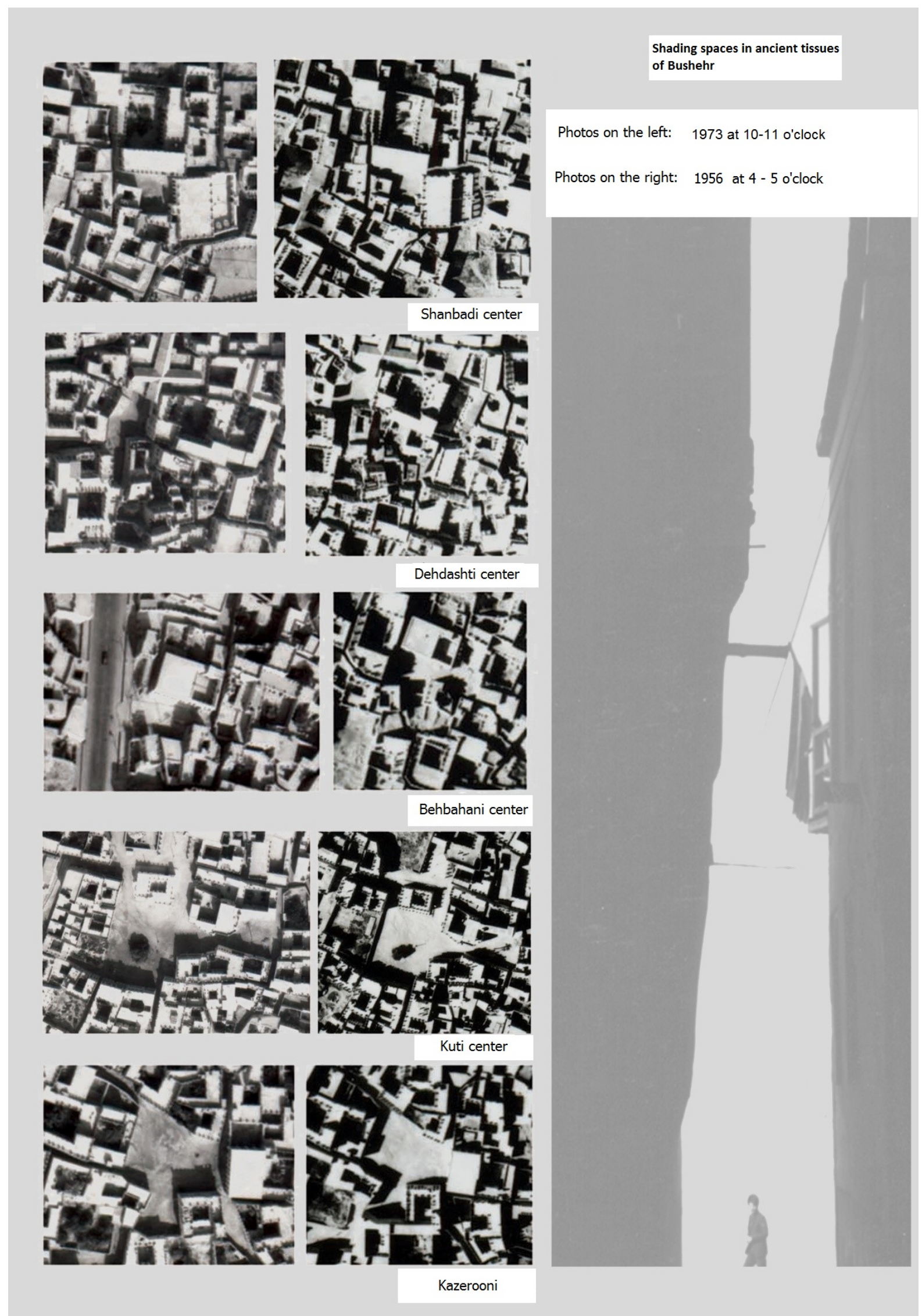

Submit Date: 05.06.2016, Acceptance Date: 23.07.2016, DOI NO: 10.7456/1060AGSE/070

Copyright (The, Turkish Online Journal of Design, Art and Communication 
Buildings are in two or three floors with coordinated height and central courtyard and rooms with doors open to the alley on the one side and on the other side to the yard; and moisture in the ground floor and air flow on top, brought life to the upper floors; and ground floor was used for storage, kitchen, bathroom and so on. One of the important elements in Bushehr architecture was central courtyard which has special characteristics. First, the yard is quite regular. Second, the size of the yard is not very large for shading. Third, there is a round porch is a central courtyard that is the interface between the courtyard and the building, the porch is used for shading in the downstairs, however, it provides a space in upstairs, which makes the central courtyard usable, which means that rooms are connected with the yard as a major supplier of light. And in a normal house with a medium scale, the elements of yard include: garden, water well, tank and cistern. The central courtyard, in addition to organizing different spaces and linking their performance, has the role of ventilation for the flow of air that enters the house. Drafts provide the ability to tolerate heat and humid air. Narrow and tall streets and full shade made it possible so that refreshing sea breeze flows into depth of the port houses. Extraversion and joint bodies in neighborhoods with the goal of having the lowest maximum use of air flow, made tissues of Bushehr separated into blocks, from one to several residential units in each one. Blocks with an irregular network of small streets that cross squares and reach the sea. The intelligent architecture of Bushehr in biological culture that compliance with environmental conditions is visible. The establishment of different functions together, despite the small size of the city and maintaining the characteristics of typical architecture, has doubled the tissues richness. Mosques and community centers, markets and businesses, Amiriyeh and consulates together constitute a variety of valuable housing elements of this historical tissue. (Jabarnia et al., 1999: 148)

\section{floors and height}

One aspect of tissue height adjustment is associated with the climatic location and topography of the site. The view to the height of buildings in the tissue implies that overall height difference as can be seen in the tissue, besides the proximity of the floors in the same buildings. The height difference can be seen on a smaller scale residential units. From the viewpoint of sunshine, the shading of buildings on each other is quite clear with height differences. This issue corresponded to receive less heat in buildings with eastwest orientation. The outdoor shading in addition to bringing a comfort, cool items during the day, followed by heat transfer from the human body to the wall and providing the thermal comfort. The height of buildings in the tissue reveals another issue, which is the placement of tall buildings, which are mainly aristocratic house, among shorter buildings. This particular issue can be seen on the edge of open spaces. The special role of height difference can be seen in the wind turbulence and wind movement at lower levels. In general, wind patterns in the ancient tissues of Bushehr can be viewed at three levels:

- The first level, the height of wind that enters tissue in collision with high rise buildings.

- The second level, space in the courtyard of the building in floors above the ground floor.

- The third level, open spaces in pathways and tissue that has the greatest impact on humans in space.

The distribution of the height of buildings in the tissue clearly shows the intelligently design of tissues.

\section{URBAN DESIGN IN THE NEW TOWN OF ALI SHAHR}

Revised plan in Bushehr was approved by the High Council of Architecture in Iran in March 1985. Under the terms of the decree, it was decided that "due to the natural limits of land for urban development and occupation of the city of Bushehr by military installations" studies on the "overflow population transfer to further local, especially in remote areas or Choghadak located in eastern Bushehr, or transferring the air force to other convenient place and freeing up the occupied land for the development of the city" be carried out.

It is important to mention here that not only the development of the northern part, the core of the city, since the establishment of naval and air forces in the area was limited, but also the development of 
southern part of the city after the establishment of a nuclear energy center in the southern point of the island is very limited. Thus, for the sake of safety rules, urban residential areas are prohibited to be made up to $10 \mathrm{~km}$ radius from the center of atomic energy plant and the southern part of the city, where it is located just outside the $10 \mathrm{~km}$ radius of the plant, although is authorized under development, but is placed under density restrictions. Bushehr Island is covered by water in some seasons and building construction is not impossible, it will have problems at least that puts only two ways for continued development of the city of Bushehr ahead. These include: (Consulting Engineers of City and planning, 1382: 141)

\section{The transfer of the Air Force to other convenient place}

2. Development of city on the height, i.e. raising population density and building, only in the northern part of the town

Both these solutions seemed impossible due to technical and financial constraints because, firstly, defense and military installations located in the central area eliminated the possibility of joining two sections of the city is and transferring them requires huge investments and secondly, increasing the density and urban development in height (in contrast with the perceived limitations of the terms of atomic energy) requires engagement with complex issues in the areas of social ownership issues related to living in apartments, allocating a large amount of urban land for public use, a general revision of the existing municipal facilities and equipment, etc.. To this end, in 1986 the initial ideas of locating a new city as in east of Bushehr was formed under the name of Ali Shahr.

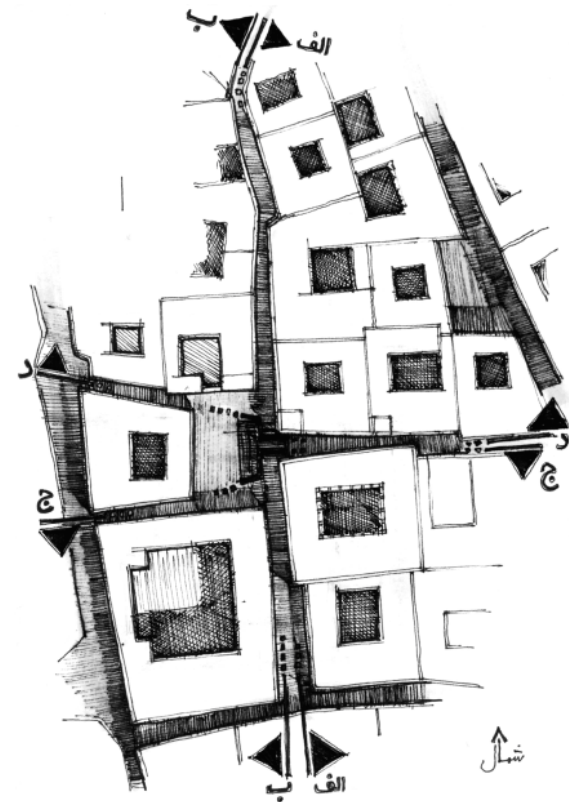

Fig 19: The combination of mass and

space in the historical tissues of

Bushehr. source: ibid

\section{Challenges in the spatial organization of the extensive area}

Vision on how urban design and architectures of monuments and generally elements of physical-spatial of Ali Shahr, considers the need to review and analyze the concept and architecture of the surrounding urban tissues necessary and in this regard Bushehr as a center and main reference in shaping the new town of Ali Shahr has a special place. Thus, as has been mentioned many times in this article studying topics related to the field of urban planning and architectural tissues of Bushehr is an important issue. Although the format, scope and content of the new town of Ali Shahr is far from visual identity and urban 
landscape, a new attitude in this regard and presenting the achievements of the previous phases of the project for use on different surfaces must be considered. Ali Shahr existing urban tissues represents a preferred organization of distribution and lack of physical space, which lacks the most important characteristic of a city. This needs considerations due to the fact that Bushehr old tissues and historical sites are compact. As noted above, the compression in the local tissues in addition to a physical-spatial organization, has a significant role in coping with adverse climatic conditions. In order to revise and review the distribution of blocks and communication networks in low scales space at local level, in other words changing the concept of neighborhood unit can be effective in modifying the physical structure of the city, readability and richness of urban landscape and consequently improves the quality of the urban environment. Determination and locating public open spaces and revising and redesigning abandoned spaces in neighborhoods of the city by using climatic patterns in ancient tissues of Bushehr are including subjects in this study.

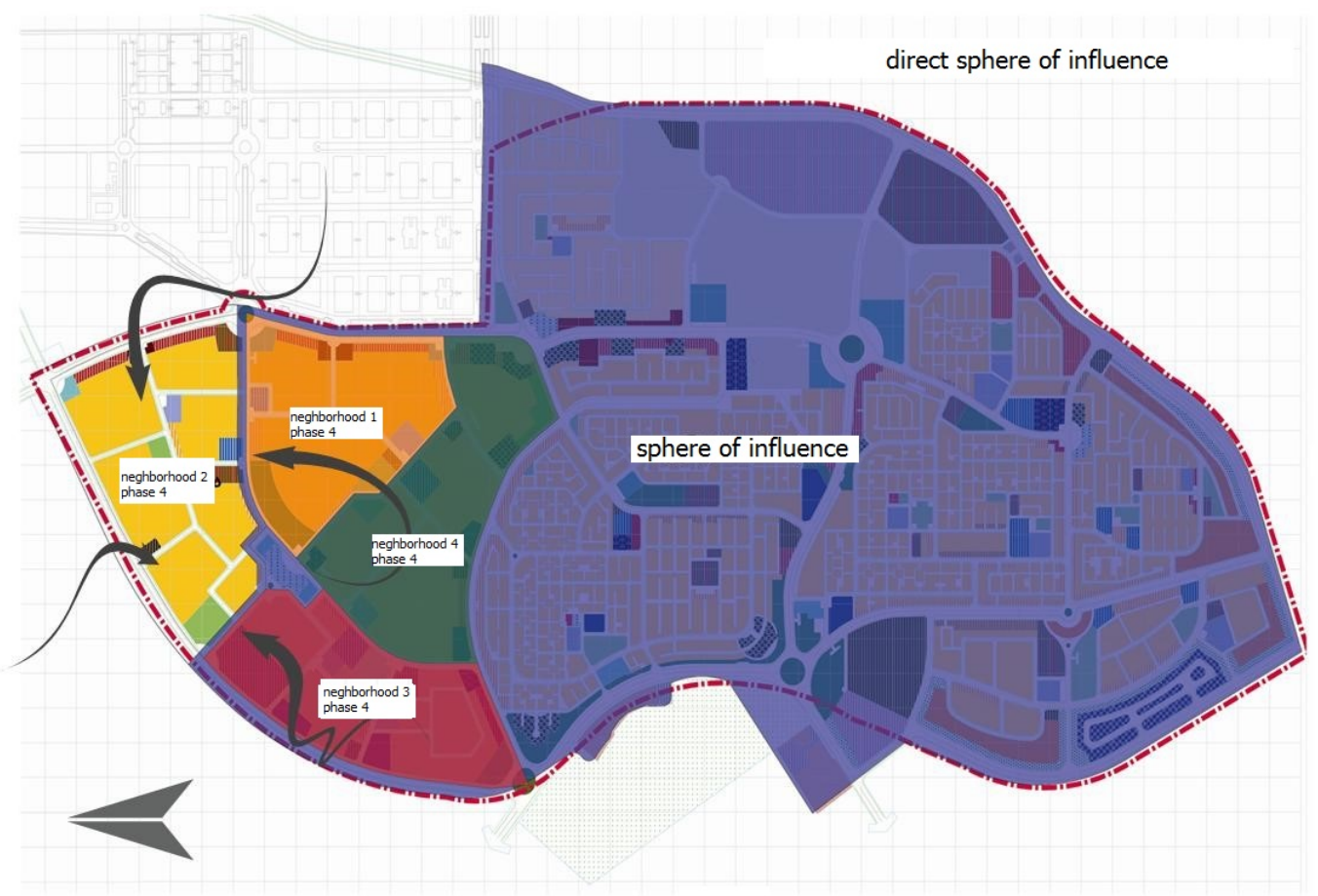

Fig 20. Design platform location in sphere of influence, source: ibid

\section{assessment of current status of direct sphere of influence reasons for selection of project site}

New Town of Ali Shahr Development Company with the policy of urban development in order to achieve the population vision was settled at the end of the Fourth Development Plan (25 thousands) and impetus for the development of so-called urban development put the plan preparation of neighborhood 2 of phase 4 in Ali Shahr in their program priorities to provide groundwork for the development of the land in the north of the city in the near future. It should be noted that the project site within the detailed plan is prepared by the consulting engineers of Aseman Naghshine firm. 


\section{general characteristics of neighborhood 2 of phase 4 in Ali Shahr}

According to urban divisions in the detailed plan prepared by consulting engineers of Aseman Naghshine firm in 2004 that was approved by the Supreme Council of Architecture and Urban Planning, project platform is located (sphere of influence) at Phase 4 of Ali Shahr. This area is located in the northern end of the detailed plan and is connected 32 meters St. from the north and northwest and is connected to artery of the two branches from the East, South and South-West. 125 hectares area was considered to accommodate a population of 16625 people. The area is divided into four quarters. An area of 36 hectares and a population of 4788 people is considered in the neighborhood 2. Neighborhood 2 is limited in the north and north-west to the detailed plan and from the south and east to artery bypass 2 . According to national documents, educational spaces such as kindergartens, primary schools (boys and girls) should be foreseen in this area. Commercial services related to the daily purchase can be predicted at the center of the neighborhood. Worship spaces such as mosques and religious-cultural services must be considered in the neighborhood. The creation of parks and gardens in the neighborhood are the needs of children in the neighborhood (consulting engineers of Aseman Naghshine, 2002: 95).

\begin{tabular}{|c|c|c|c}
\hline \multicolumn{3}{c}{ The physical division of sphere of influence. } \\
\hline $\begin{array}{c}\text { Gross } \\
\text { density } \\
\text { (Persons } \\
\text { per } \\
\text { hectare) }\end{array}$ & population & Area & neighborhood \\
\hline 133 & 3724 & 28hectare & 1 \\
\hline 133 & 4788 & $36 h e c t a r e$ & 2 \\
\hline 133 & 3990 & $30 h e c t a r e$ & 3 \\
\hline 133 & 4389 & 33hectare & 4 \\
\hline 133 & 16625 & 125hectare & Total area \\
\hline
\end{tabular}




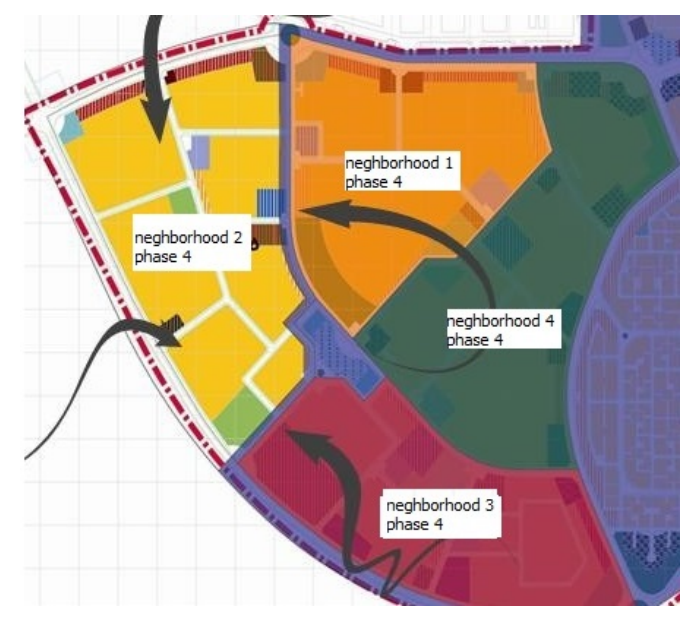

Fig 21. Design platform location in sphere of influence, source: ibid

\section{formulating conceptual solutions}

The design requires a complex mental process of ability to pinpoint a wide variety of information, their combination in a coherent body of ideas and ultimately the creation of implemented form of ideas. As mentioned many times throughout this article, the influence of climatic characteristics on human settlements are some factors that affect the qualitative and quantitative characteristics of settlements to a large extent. These factors in the historic tissues of Bushehr and public spaces made living in the harsh climate easily tolerable and has granted an identity to the city's architecture and urban planning.

New look to architecture and urban planning at Bushehr and Ali Shahr indicate distortion and to some extent ignoring the principles and criteria of this city in tissue formation. This discontinuity, is caused by the look of modernist in urban design that nearly affected all new tissues. Thus, as noted emphatically design solutions in new towns without taking into account climatic issues, the city and its neighborhoods make tissues inefficient and uninhabitable and anonymous.

Given the importance of this issue, this research discussed principles and standards of urban planning and architecture of Bushehr under the influence of climatic factors on two levels, and in connection with the development and analysis of climate data. In urban areas, factors such as adherence to the structure and form of the climate, space and military organizations height, density, plants, extraversion or introversion trait of tissues, passages and corridors, neighborhoods and open spaces and centers and in the field of architecture factors such as the distribution of the components, the relationship with the public realm, diversity of housing, building materials and colors, architectural proportions, shading and climatic comfort, ventilation etc. are examined.

The article in regard to the background and location of Ali Shahr, needs of today's residents as well as changes in the use of space, the concept of public space through time and space were classified in form of concept ideas and solutions and presented under two different options (alternative) design approach for all of a pice urban design; as they can be useful since they are derived from the heart of the historic tissues of Bushehr. In designing the options we tried to achieve opposing ideas with a coherent and comprehensive structure. Design is based on a conceptual project and aimed to achieve a familiar atmosphere but with the new image in terms of climatic factors. In another sense a new expression is designed to differentiate its form but keeps its nostalgic atmosphere of the past. Perhaps this description of ideas in the minds of the authors of may not express all aspects. 
Fig 22: semi-public spaces (local streets) and semi-private space (shared courtyard) - Neighborhood 2 phase 4 alternatives (2) Source: authors

\section{Climatic design principles and instruments in Ali Shahr}

As stated climatic conditions along with other environmental factors are the most important factors in the formation of cities. Cities and urban elements and their performance have been affected by climatic elements and factors and this influence was one-way prior to the formation of big cities but then they became influential on climatic conditions and have created climate change in their environment.

With the effect of Bushehr climate on urban design of ancient tissues, climatic effects and their use in the design and development of neighborhood 2 of phase 4 of Ali Shahr were determined. Through climatic factors one may achieve the most appropriate ways and forms such as living spaces and architecture, monuments intervals for network access and increasing the amount of shading in Ali Shahr.

\section{protect buildings against hot air}

- Construction of buildings against the hot air flow

- Confined spaces often used in hot periods with heavy materials and insulation, and used spaces with light materials

- Predict the compact and dense buildings

- Separate exothermic spaces, like kitchen

- Use thermal insulation with any type of materials preferably local materials

- design the windows with low width and high height

- The use of double-glazed glass

- use wooden window or mobile networks thermal insulation in the window

- Use double-shell roof

- Use bright colors on facades and walls

building protection against the sun

- Avoid the slopes facing the East or West for construction

- Establishment of building in minimized direction of sunlight

- Choose appropriate materials for spaces around the building to minimize heat

- Use deciduous trees to create shade on buildings in periods of cooling and warming

- Use right physical shape to reduce the external surfaces facing the East and West (east - west building plans)

- Greater use of common walls in the building and create a compact tissue

- Indoor parking space rather than garage and putting it in the western part of the building

- Open main spaces located in the shadow to the courtyard

- using the ventilation space under the roof, double layered roof with thermal insulation 
- Use bright colors and not too rough surface on the roof and exterior walls facing the sun

- Avoid creating windows in the roof, except in the summer if it is quite shadow

- Avoid creating windows, especially in the eastern and western facades, otherwise limit the number and size of such windows and using vertical shades for them.

- Use roof saliency, loggia or balcony to create the perfect shade on the outer surface of the window glass and the walls of the openings facing the sun

- Use proper canopy (if possible, external shading devices) for glass surfaces and openings

- Use wooden windows or mobile insulation grids in windows

- Use outer space, to use when the air is fine

- Use the console at the proper height, especially in the body adjacent to walkways to create shading

\section{create drafts in interior spaces}

- maximize air flow around the buildings by creating a proper distance between them

- The establishment of structures in direction of favorable winds and using high ceilings

- Design elements of the area so that plants direct the favorable winds inside

- Plan and organize the building plan in a way that allows air circulation around the building

- Planning the building for maximum ventilation at the top, bottom and inside the building

- Using plans with thin sections

- Use the stack (increasing the height of the central spaces)

- Doors between rooms by the controllable walls to direct the air flow

- The use of large and opening doors and windows

- The use of upper and lower windows to improve ventilation conditions at night

- use at least two windows, one facing the wind and opposite one

- use the external space due to favorable breezes

\section{prevent humidity increase}

- Avoid covers in parts in which winds direct the moisture to interior spaces

- Control humidity of plants by air stream

- Use permeable materials in the bottom of premises and prevent water retention in areas under the sunlight 

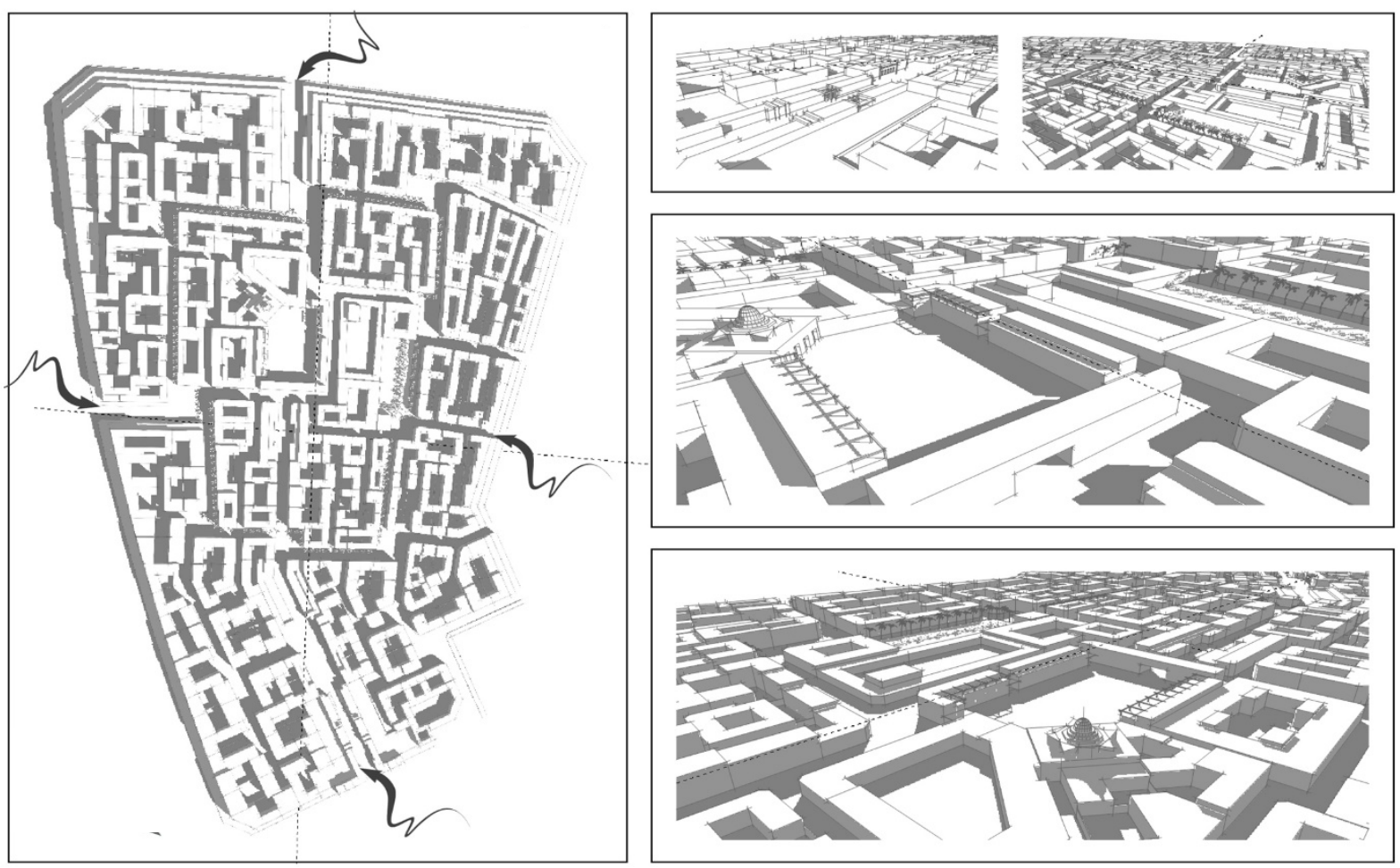

Fig. 23: three-dimensional Master Plan Neighborhood 2 phase 4 of Ali Shahr (combination of mass and space) alternative (1) Source: authors

\section{CONCLUSION}

Urban development by new towns policy in the country have a major impact on the environment and living conditions for humans, animals and plants. Most of these changes in the fields of medicine, agriculture and engineering has been surveyed by experts. The major impact of climatic conditions on new towns and settlements and urban development plans is considered little. The purpose of this article, as was repeatedly pointed is to reduce the negative impact of the environmental condition of Ali Shahr through the exploitation of climate patterns in the old tissues of Bushehr in order to control solar radiation, cooling and building natural draft. And the ultimate goal is to create umbrella shade or a region free of solar radiation which is suitable to live in hot and humid areas. As noted above, the effects of climate on the type and form of development, to achieve design strategies in urban spaces and architecture is essential to walking, mobility and activities of people in urban areas in terms of convenience so that life within buildings under normal conditions and with less reliance on mechanical ventilation devices be possible.

Traditional solutions in response to the climate in the design of cities and buildings has been forgotten. In urban areas due to population growth in these areas and changes in lifestyle and vital resources such as water, urban management in new cities need to be revised in terms of using climatic patterns of ancient tissues to improve the design of cities and buildings. Although methods to create comfort by using climatic factors such as wind and shade are well-known to some extent in the design of buildings, optimal use of microclimate in urban spaces due to the nature and its complexity is difficult problem. This arises from the use of urban spaces during hot and humid periods of year in areas such as Bushehr and Ali Shahr is very high and without the use of urban spaces dynamism and urban vitality of the area will diminish. 
Thus creating balance and somewhat achieving comfort in urban spaces, such as inside buildings by the city managers will be necessary; and taking advantage of climatic patterns in the region is very important.

\section{REFERENCES}

Bagheri Beheshti, "the public arena, neglected areas in new towns", Proceedings of the International Conference on New Towns, the second book (the identity of new towns), 2006, 68-61

Rajai and Zahmatkesh "The role of geographical and environmental factors in locating new cities", Proceedings of the International Conference on New Towns, the second book (the identity of new towns), 2006, 234-219

Ranjbar, "climate stability criteria in the design of urban public spaces of modern cities of the Persian Gulf, Case Study: Bushehr-Ali Shahr", urban design master thesis, Faculty of Art and Architecture, Tarbiat Modarres University, Tehran, 2007

Zanjani, Safdari, "a new approach in the assessment and locating new towns and cities", Journal of Architecture, No. 65, Winter 2009, 9-6

Abedi, Safdari, "new towns-compliance with the requirements of the human sense of place", Journal of Architecture villages, No. 65, Winter 2009, 77-72

aghighi, "legal evolution of modern cities", Journal of Architecture, No. 65, 2009,29-26

Gander, "wind effect on the formation of urban spaces" Translator: Jenab, Consulting Engineers / Tehran / 1994

Aseman Naghshine, detailed plan of the new city with 500 hectares of Ali Shahr, New Towns Development Company, Tehran, 2002

Consulting Engineers, Jabarnia et al., Renovation and Revitalization project of Bushehr, the Department of Housing and Urban Development, Bushehr, 1999

Consulting Engineers of city and Planning, the new city plan studies for Ali Shahr, New Towns Development Company, Tehran, 1993

Consulting Engineers of city and Planning, master plan studies of Bushehr Province, Department of Housing and Urban Development, Tehran / 2003

Baruch, Givoni/ Climate Considerations in Building and Urban design/ Van Nostrand Reinhold. NewYork/1998

Baruch, Givoni/ Urban Design and Climate/ Time-Saver Standard for Urban Design/Mc Grawhill/New York/2003

Baruch, Givoni/ Urban Design for Hot Humid Regions/ Renewable Energy/1994 